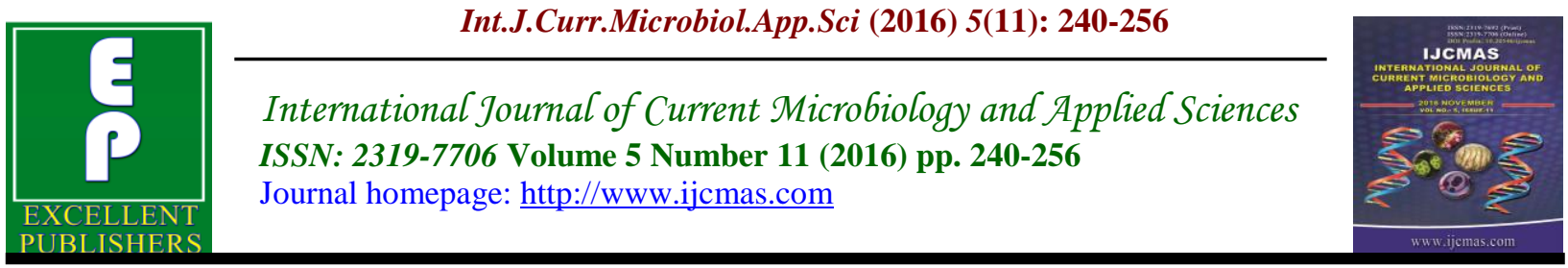

Original Research Article

http://dx.doi.org/10.20546/ijcmas.2016.511.026

\title{
Antimicrobial Activities Evaluation from the Extracts of Leaves, Flowers, Fruits and Latex of Calotropis procera from Taif
}

\author{
Abd-El Aziem Farouk ${ }^{1,2}$, N. Thoufeek Ahamed ${ }^{1}$, Othman AlZahrani', \\ Khalid H. Alamer ${ }^{3}$ and Abdul Aziz Bahobail ${ }^{3}$ \\ ${ }^{1}$ Molecular Biotechnology Research Unit, Department of Biotechnology, Faculty of \\ Science, Taif University, Al-Hawiya 888, Kingdom of Saudi Arabia \\ ${ }^{2}$ Tsuno GmbH, Wibiloweg 16, 69123 Heidelberg, Germany \\ ${ }^{3}$ Department of Biology, Faculty of Science, Taif University, Al-Hawiya 888, \\ Kingdom of Saudi Arabia \\ *Corresponding author
}

\section{Keywords}

Agar well diffusion method, antimicrobial activities, Calotropis procera, medicinal plant extract.

\begin{tabular}{l}
\hline Article Info \\
\hline Accepted: \\
12 October 2016 \\
Available Online: \\
10 November 2016
\end{tabular}

\section{A B S T R A C T}

Antimicrobial activities evaluated from leaves, flowers, fruits and latex of locally obtained Calotropis procera from Al-Sharifieya, Taif in different aqueous solutions and solvents such as sterilized Zamzam water and distilled water, ethanol, acetone, isoamyl alcohol and $100 \mathrm{mM}$ Tris- $\mathrm{HCl}$ at $\mathrm{pH} 8.7$ by using liquid Nitrogen. Calotropis procera was subjected to a standard agar well diffusion method. The ethyl alcohol extract of leaves of Calotropis procera showed an activity against both Pseudomonas aeruginosa ATCC 27853 and Candida albicans ATCC 10231 with a concentration of $200 \mathrm{mg} / \mathrm{ml}$ clearing zones $10 \mathrm{~mm}$ in diameter. The Tris$\mathrm{HCl}$ at $\mathrm{pH} 8.9(100 \mathrm{mM})$ extracts of leaves extracts also showed the highest antimicrobial activity against Pseudomonas aeruginosa ATCC 27853 with same concentrations (diameter $12 \mathrm{~mm}$ ). The ethyl alcohol extracts of flower and latex showed antimicrobial activity against Bacillus subtilis ATCC 6633 with same concentrations (diameter $10 \mathrm{~mm}$ and $8 \mathrm{~mm}$ ). Among the different solvent extracts of Calotropis procera, the distilled water and Zamzam water extracts of leaves, flower, fruit, latex and Tris- $\mathrm{HCl} \mathrm{pH} 8.9(100 \mathrm{mM})$ extracts of fruits and latex showed activity against Bacillus subtilis ATCC6633 with the same concentration (diameter $8 \mathrm{~mm}$ ). Similar inhibitions (zones of 4-6 mm) for Zamzam and sterilized distilled water extracts of fruit of Calotropis procera were seen for the Escherichia coli ATCC 8739, Micrococcus luteus ATCC 9341 and Pseudomonas aeruginosa ATCC 27853. In isoamyl alcohol and acetone extracts of fruit activity was observed in all four bacteria.

\section{Introduction}

A small tree like Calotropis procera is widely available in Taif, the mild deserted climatic city in the Mecca Province of Saudi Arabia's Sarawat Mountains. The leaves, flowers, latex, roots, and bark of Calotropis procera which belongs to the Asclepiadaceae family (Verma et al., 2010) generally grow up to 2.5 - 4 meter (max. 6 meter) high. The evergreen, perennial shrub is a popular medically important plant which deals with many human and animal diseases. 
Calotropis procera is native to West Africa, Madagascar, the Arabian Peninsula, Southern Asia, India and China with common names: auricula tree, cabbage tree, calotrope, camel tree, dead sea fruit, desert wick in English; dead sea plant, kisher and usar (usher in Arabic). It is also known as sodom apple or French cotton.

Taxonomically, it belongs to the domain: eukaryota; kingdom: plantae; phylum: spermatophyta; subphylum: angiospermae; class: dicotyledonae; order: entianales; family: apocynaceae; genus: Calotropis; species: Calotropis procera. Calotropis procera is very much linked to the ornamental plant $C$. gigantea, which is sometimes misidentified as Calotropis procera. It has $10-20 \mathrm{~cm}$ long and $4-10 \mathrm{~cm}$ wide leaves, multi flowered with 5 sepals that are $4-5 \mathrm{~mm}$ long; Fruits are subglobose, ellipsoid or ovoid, with recurved follicles, 7.5-10.0 cm long. Flowering and fruiting take place throughout the year. The plant lives about 12 years (Little et al., 1974; Francis, 2002).

This plant is alexipharmic and cures leprosy, ulcers, and spleen and liver diseases. The juice is anthelmintic, used as a laxative, and cures piles. The flowers are analgesic, astringent and cure inflammations as well as tumors. Mascolo et al., 1988 reported activities of flower extracts against swelling and fever in rats, and also antimicrobial activities. Calotropis procera is used for diarrhea, sinus fistula, and skin disease (Alikhan, 2005; Raghubir, 1999).The leaves are used as an antidote for snake bite, sinus fistula, rheumatism, mumps, burn injuries, and body pain. The leaves of Calotropis procera are also used to treat jaundice. The flower contains bioactive compounds such as sterols, flavonoids, calotropin, saponins, tannins, phenols, coumarins, polysaccharides and enzymes (Rama, 2012). The spongy fruits consist of brown seeds which also have antimicrobial activity. The latex of Calotropis procera is used in conventional medicine as an antisyphyilitic, purgative, and antiodontalgic agent and as a cure for verrucas. Extracts from latex, leaves and flowers in Morocco had more effect on yeasts than on fungi (Larhsini et al., 1997). In the Unani system of medicine, Calotropis procerais used in treatment for scabies, ringworm of the scalp, piles, asthma, liver, leprosy, and spleen enlargement, and dropsy. Different parts of Calotropis proceraare are used in several Ayurvedic systems of medicinal preparations (Murti, 2010). Extracts from Calotropis proceralatex have larvicidal activity against mosquitoes (Markouk et al., 2000). Activities against plant pathogenic fungi have also been reported (Singh et al., 1996, Shivpuri et al., 1997). C. procera's usages were also reported (Agharkar, 1991; Ansari, 1999; Dewan et al., 2000; Markouk et al., 2000; Samvatsar, 2000; Sharma et al., 2011). The milky latex is used in traditional medicine to cure skin infections, poison, ulcer, enlargement of spleen, liver, abdominal glands, colic piles, worms and different inflammatory diseases (Lima-Filho et al., 2010). The latex had mild toxic effects on heart, liver and kidneys; that included multi-focal coagulation necrosis of cardiac fibers and vacuolized hepatocytes (Magalhaes et al., 2010).

Antimicrobial activity of Calotropis procera was reported earlier (Jain et al., 1996 and Kareem et al., 2008.). Different proteins like laticifer (Souza et al., 2011) and osmotin from the latex of Calotropis procera reportedly exhibit potent anti-fungal, antimycoplasmal (Muraina et al., 2010), anti-inflammatory properties (Lima-Filho et al., 2010, Kumar, 2011). Protective effects of proteins derived from the latex of Calotropis procera work against inflammatory hyperalgesia in monoarthritic 
rats and exhibit anticancer properties (Morsy et al., 2001; Shahi et al., 2010; Ali El-Rabaa 2010; Oliveira et al., 2010). In vitro antimicrobial, antifungal and antiviral screening revealed that the ethyl acetate extracts were effective in suppressing the bacterial pathogens Pseudomonas aeruginosa, reported by Subramanian et al. Calotropis procera is well known for its ability to produce several biologically active compounds (Silva, 2010). The plant parts have exhibited antimicrobial (Ishnava, 2011), antifungal (DeFreitas, 2011), antiviral (Oliveira, 2010), anticancer (Silva, 2010), anti-inflammation (Kumar, 2011), antioxidant (Mst Nazma et al., 2008) and wound healing properties (Romar, 2012, Yesmin et al., 2008). It is emetic (Njama, 2009) and has an anti-inflammatory properties (Soneera, 2005).

In our Lab, the five bacterial strains used in the antimicrobial assay are 1) gram-positive bacterium Bacillus subtilis (hay bacillus or grass bacillus) (Madigan, 2005) allowing the organism to resist intense environmental conditions; 2) Micrococcus luteus (family microoccaeae), a gram-positive, spherical, saprotrophic bacterium (Madigan, 2005) present in normal flora of the mammalian skin; 3) Escherichia coli, a gram-negative, rod-shaped bacterium normally harmless, found in the lower intestine of warmblooded organisms (Russo, 2003); 4) Pseudomonas aeruginosa, (family pseudomonadaceae) a gram-negative, aerobic rod, cocco-bacillus bacterium is commonly seen in soil and water (Lederberg et al., 2000). It is pathogenic to plants found on the surfaces of plants and animals. It causes urinary tract infections, bone $\&$ joint infections, gastrointestinal infections, soft tissue and respiratory system infections, dermatitis and a variety of systemic infections, it is also found mainly in patients with brutal burns, with cancer, and sufferers of immune suppression; 5) Candida albicans, a diploid fungus found as both yeast and filamentous cells, causing oral and genital infections. (Ryan, 2004; Enfert, 2007).

This project study on the parts of Calotropis procera i.e. "Antimicrobial Activities Evaluation from the Extracts of Leaves, Flowers, Fruits and Latex of Calotropis procera" was conducted at Molecular Biotechnology Research Unit, Department of Biotechnology at Taif University.

\section{Materials and Methods}

The Calotropis procera parts used in this experiment were collected from $\mathrm{Al}$ Sharifieya, Taif in early morning hours. The fresh leaves and flowerers were found with buds and open ones. All flowers were kept in fridge initially for 2 hours to avoid wilting. Calotropis procera leaves, flowers, $\&$ fruit were weighed individually to 200 mg. The latex (milk) was extracted directly from the plant aseptically. The selected leaves were $6-15 \mathrm{~cm}$ long and $4.5-8 \mathrm{~cm}$ broad, broadly ovate or ovate-oblong in shape, elliptical, pubescent when young and glabrous on both sides on maturity.

The Zamzam water was obtained from the bottling factory under the Saudi Ministry of "King Abdullah Bin Abdul-Aziz Zamzam Project" distribution station in Kuday, Mekkah. The clear, colourless and odourless Zamzam water used in this study has a distinct taste due to its $\mathrm{pH}$ of 7.9-8.0, (slightly alkaline). It contains Sodium 133mg/l; Calcium 96mg/1; Magnesium 38.88mg/l; Potassium 43.3mg/l; Bicarbonate $195.4 \mathrm{mg} / \mathrm{l}$; Chloride 163.3mg/l; Fluoride $0.72 \mathrm{mg} / \mathrm{l}$; Nitrate $124.8 \mathrm{mg} / \mathrm{l}$; Sulfate 124.0 $\mathrm{mg} / \mathrm{l}$ and a total dissolved alkalinity of 835 mg/l (Nour Al Zuhair et al., 2010; Shomar, 2012). 
The freshly obtained Calotropis procera leaves, flowers \& fruit were cleaned with sterilized distilled water and ethyl alcohol. They were taken in mortar and pestle, the liquid nitrogen was poured and homogenized into a fine powder in order to increase its surface area to facilitate the extraction procedure. Fig. 1 shows the flowchart of the methodology.

The bacterial strains used were Bacillus subtilis ATCC 6633; Candida albicans ATCC 10231; Escherichia coli ATCC 8739; Micrococcus luteusATCC 9341; Pseudomonas aeruginosa ATCC 27853 Note: (ATCC: American Type Culture Collection).

The solvents of extraction were Zamzam water; distilled water; ethyl alcohol; isoamyl alcohol; acetone and Tris- $\mathrm{HCl}$ at $\mathrm{pH} 8.7$, $(100 \mathrm{mM})$. The solvents sterilized water and Zamzam water were prepared by autoclaving at $121^{\circ} \mathrm{C}$ at $15 \mathrm{psig}$ for 20 minutes. The ethyl alcohol, isoamyl alcohol, acetone were purchased from Loba Chemie Pvt. Ltd., Mumbai and Tris- $\mathrm{HCl}$ at PH8.7 (100 mM) was prepared in our lab. The chemicals used were liquid nitrogen; nutrient agar; nutrient broth; $\mathrm{NaOH}$ was also purchased from Loba Chemie Pvt. Ltd., Mumbai.

An overview of the entire experiment is shown in Figure 1. The water, acetone, ethyl alcohol, isoamyl alcohol and $100 \mathrm{mM}$ Tris$\mathrm{HCl}, \mathrm{pH} 8.7$ ) were used for extraction and the $1.0 \mathrm{ml}$ of extract collected were kept in a shaking incubator at $30^{\circ} \mathrm{C}$ for $2 \mathrm{hrs}$.

The Calotropis procera leaves, flowers, fruits \& latex containing bioactive components were subjected to extraction procedures. $200 \mathrm{mg}$ of the powdered material was dissolved in $1.5 \mathrm{ml}$ of each of the solvents. The organic solvents have a high polarity and were able to dissolve a big amount of the compounds.
The powdered material $(200 \mathrm{mg}$ ) and latex (200mg) were extracted with $1.5 \mathrm{ml}$ of corresponding solvents (The sterilized Zamzam water, sterilized distilled water, acetone, ethyl alcohol and $100 \mathrm{mM}$ Tris$\mathrm{HCl}, \mathrm{pH} 8.7$ ) were used for extraction and the $1.0 \mathrm{ml}$ of extract collected was kept in a shaking incubator at $30^{\circ} \mathrm{C}$ for 2 hours. The organic solvents and water extract was filtered and evaporated until dryness. The extract was stored at $4^{\circ} \mathrm{C}$ until further use.

The individual fractions were then centrifuged at 10,000 rpm for 10 minutes. After centrifugation, the supernatant was kept at $-20^{\circ} \mathrm{C}$. Each extract was prepared and named.

Four parts each of $200 \mathrm{mg}$ of Calotropis procera was dissolved in six corresponding solvents i.e. a total of 24 samples was used for the study of "Antimicrobial Activities Evaluation from the Extracts of Leaves, Flowers, Fruits and Latex of Calotropis procera". After extraction the tubes were kept in the shaker at $150 \mathrm{rpm}$ at $30^{\circ} \mathrm{C}$ for 2 hours and then kept in freezer at $-80^{\circ} \mathrm{C}$.

The agar plates were made by taking 28 grams of nutrient agar obtained from Himedia Lab Pvt. Ltd, Mumbai, India and dissolved in 11 of sterilized distilled deionized water. The composition of nutrient agar was Hiveg peptone 5.00 grams/liter; Hiveg. extract 1.50 grams/liter; yeast extracts 1.50 grams/liter; sodium chloride 5.00 grams/liter and agar 15.00 grams/liter. Final $\mathrm{pH}\left(\right.$ at $25^{\circ} \mathrm{C}$ ) was 7.4 . The solutes were shaken until they dissolved and the $\mathrm{pH}$ was adjusted to 7.4 using sterilized $1 \mathrm{~N} \mathrm{NaOH}(8 \mathrm{ml})$. The volume was adjusted to $1 \mathrm{~L}$ with deionized water. The solutes were sterilized by autoclaving at $121^{\circ} \mathrm{C}$ for 20 minutes at $15 \mathrm{psi}(1.05 \mathrm{~kg} / \mathrm{cm})$ on liquid cycle. Autoclaved medium was swirled gently for even distribution of the melted agar in the solution and allowed to cool to 
50 to $60^{\circ} \mathrm{C}$. Under sterile conditions $20 \mathrm{ml}$ of this medium was poured on to $90 \mathrm{~mm}$ Petri dishes and again allowed to cool. After the medium sets completely, inverted Petri dishes were stored at $4^{\circ} \mathrm{C}$ and removed from storage 1-2 hours prior to use (Sambrook, 2001).

The five bacterial strains were maintained on nutrient agar and freshly prepared subcultures in nutrient broth were used during this project. This was done by transferring two or three colonies into a bottle containing $20 \mathrm{ml}$ of liquid nutrient broth medium and grown for 24 hours (or overnight) at $37^{\circ} \mathrm{C}$ and a small aliquot was poured on plates and dried.

The standard agar-well diffusion method (Collins et al., 1995) was employed to determine the antimicrobial activities for both acetonic and aqueous Calotropis procera extracts. The agar was cooled to 50$60^{\circ} \mathrm{C}$ before adding any thermo- labile substances. The suspension of the bacterial cultures was covered wholly on the agar plates and allowed to dry. Then, in the nutrient agar 18 or 19 wells $(6 \mathrm{~mm}$ diameter) were made on each plate using sterile yellow tip. Following this, $50 \mu 1$ of the test solution i.e. the supernatant of Calotropis procera extract were added inside the laminar flow cabinet for 15-20 minutes to allow the solutions in the wells to diffuse. The agar plates were then inverted and incubated for 24 hours at $37^{\circ} \mathrm{C}$. After incubation, clear areas in the region of the wells containing antimicrobial compounds appeared. This diameter of the clear area (called the inhibition zones) around the wells were measured and recorded. Antimicrobial activities of each solvent extract were expressed in terms of average diameter of the inhibition zone (evaluated in milliliter). Each Calotropis procera extract was tested in the same manner. The concentration and solvents that give the optimum result were identified.

\section{Results and Discussion}

Antimicrobial activity of leaves extracts $(200 \mathrm{mg} / \mathrm{ml})$ of Calotropis procera against different types of pathogenic bacteria: The distilled water and Zamzam water extracts of leaves extracts of Calotropis procera showed antimicrobial activity against Bacillus subtilis ATCC 6633, the inhibition zones were measured to be $8 \mathrm{~mm}$ in their diameter. The water extracts of leaves extracts of Calotropis procera showed an almost nil antimicrobial activity in Escherichia coli ATCC8739 6633, Candida albicans ATCC 10231 and Pseudomonas aeruginosa ATCC 27853. The ethyl alcohol extracts of leaves extracts of Calotropis procera showed the highest antimicrobial activity against $P$ seudomonas aeruginosa ATCC 27853 and Candida albicans ATCC 10231 with clearing zones $10 \mathrm{~mm}$ in diameter whereas no antimicrobial activity was measured against Escherichia coli ATCC $8739 . \quad$ The isoamyl alcohol extracts of leaves extracts of Calotropis procera showed no antimicrobial activity in Candida albicans ATCC 10231 and in the other four bacteria's showed activity with clearing zones from 6 to 8 $\mathrm{mm}$ in diameter. No antimicrobial activity was measured against Escherichia coli ATCC 8739 with distilled water, Zamzam water and ethyl alcohol extracts of leaves extracts of Calotropis procera. The acetone extracts of leaves extracts of Calotropis procera showed antimicrobial activity in all microorganisms with clearing zones from 4 to $8 \mathrm{~mm}$ in diameter whereas no antimicrobial activity was measured against Candida albicans ATCC 10231. The Tris- $\mathrm{HCl}$ at $\mathrm{pH} 8.9(100 \mathrm{mM})$ extracts of leaves extracts of Calotropis procera showed no antimicrobial activity in Bacillus 
subtilis ATCC6633 and Candida albicans ATCC 10231 whereas equal activity in Escherichia coli ATCC 8739 and Micrococcus luteus ATCC 9341 (6 mm). (Table1).

Antimicrobial activity of flower extracts (200 mg/ml) of Calotropis procera against different types of pathogenic bacteria: The Zamzam water and distilled water extracts of flower extracts of Calotropis procera showed antimicrobial activity against Bacillus subtilis ATCC 6633, the inhibition zones were measured to be $8 \mathrm{~mm}$ in their diameter and nil antimicrobial activity in Candida albicans ATCC. The Escherichia coli ATCC 8739, Micrococcus luteus $\quad$ ATCC 9341 and Pseudomonas aeruginosa ATCC 27853 showed similar inhibitions zones from 4 to $6 \mathrm{~mm}$ for both solvents extracts of flower extracts of Calotropis procera. Like the leaf extracts, the ethyl alcohol extracts of flower extracts of Calotropis procera showed antimicrobial activity against Bacillus subtilis ATCC6633 with clearing zone each with $10 \mathrm{~mm}$. in their diameter. Also no antimicrobial activity was measured against Candida albicans ATCC 10231. Pseudomonas aeruginosa ATCC 27853 and Micrococcus luteus ATCC 9341 showed similar activity i.e. $6 \mathrm{~mm}$. The distilled water, ethyl alcohol, isoamyl alcohol and acetone extracts of flower extracts of Calotropis procera showed almost equal antimicrobial activity in Micrococcus luteus ATCC 9341, Escherichia coli ATCC 25922 and Pseudomonas aeruginosa ATCC 27853 with inhibitions zones of $6 \mathrm{~mm}$ whereas no antimicrobial activity against Candida albicans ATCC 10231. Though the Tris-HCl extracts of flower showed antimicrobial activity with inhibition zones measured 8 $\mathrm{mm}$ in their diameter against Escherichia coli ATCC 25922 and Micrococcus luteus ATCC 9341, the other three bacteria
(Bacillus subtilis ATCC 6633, Candida albicans ATCC 10231 and Pseudomonas aeruginosa ATCC 27853) showed nil activity (Table1).

Antimicrobial activity of fruit extracts (200 $\mathrm{mg} / \mathrm{ml}$ ) of Calotropis procera against different types of pathogenic bacteria: All the five solvent extracts of fruit extracts of Calotropis procera showed antimicrobial activity against Bacillus subtilis ATCC6633, the inhibition zones were measured as $8 \mathrm{~mm}$ in their diameter except Tris-HCl solvent $(6 \mathrm{~mm})$ and nil activity against Candida albicans ATCC 10231. The Zamzam water, water, ethyl alcohol, isoamyl alcohol and acetone extracts of fruit extracts of Calotropis procera showed almost equal antimicrobial activity in Micrococcus luteus ATCC 9341, Escherichia coli ATCC 25922 and Pseudomonas aeruginosa ATCC 27853 and the inhibition zones were measured positively as $6 \mathrm{~mm}$ clearances in diameter with no changes observed with Tris- $\mathrm{HCl}$ as solvent (Table1).

Antimicrobial activity of latex extracts (200 $\mathrm{mg} / \mathrm{ml}$ ) of Calotropis procera against different types of pathogenic bacteria: The Zamzam water, distilled water, ethyl alcohol and amyl alcohol extracts of latex showed antimicrobial activity against Bacillus subtilis ATCC 6633, Escherichia coli ATCC 25922, Micrococcus luteus ATCC 9341 and Pseudomonas aeruginosa ATCC 27853, the inhibition zones were measured from 6 to 8 $\mathrm{mm}$ in diameter. The antimicrobial activity of latex extracts of Calotropis procera against Bacillus subtilis ATCC 6633 with Tris-HCl with the inhibition zones were measured as $14 \mathrm{~mm}$ in their diameter. All the solvent extracts of latex of Calotropis procera had no antimicrobial activity against Candida albicans ATCC 10231 was shown (Table1). Antimicrobial activities (inhibition zones $\mathrm{mm} / \mathrm{ml}$ ) of different 
microorganisms were evaluated against standard oxytetracycline was shown in Table 2. The inhibition zones indicated with the numbers and their corresponding order of extracts of leaves, flowers, fruits and latex of Calotropis procera extracted with 6 Different solvents used were shown in Table 3. The order of extracts were denoted as LD, LZ, LE, LA , LI, LT where $\mathrm{L}$ represented Leaf extract; FD, FZ, FE, FA , FI, FT where F Flower extract; BD, BZ, BE, BA, BI, BT where B represented Fruit extract and $\mathrm{MD}, \mathrm{MZ}, \mathrm{ME}$, MA, MI, MT where M represented Latex extract; The Solvents were denoted as Distilled water (D), Zamzam water (Z) , ethanol (E), acetone (A) , isoamyl alcohol (I) and Tris- $\mathrm{HCl}(\mathrm{T})$.

In this study of the leaves, flowers, fruits and latex extracts of Calotropis procera, the evaluation of the antimicrobial activities of the extracts of Calotropis procera against above mentioned five microorganisms was carried out by standard agar well diffusion clearing zone method showed different results. The ethyl alcohol extract of leaves of Calotropis procera had shown considerable activity against both Pseudomonas aeruginosa ATCC 27853 and Candida albicans ATCC 10231 in concentrations of $200 \mathrm{mg} / \mathrm{ml}$ with clearing zones $10 \mathrm{~mm}$. in their diameter. The ethanolic extracts of leaves and flowers showed significant activity was earlier reported [13]. The Tris$\mathrm{HCl}$ at $\mathrm{pH} 8.9(100 \mathrm{mM})$ leaves extracts of Calotropis procera also showed significant antimicrobial activity against Pseudomonas aeruginosa ATCC 27853 with the same concentration (diameter $12 \mathrm{~mm}$ ). The previous antimicrobial studies with inherent isolated bacteria from sea cucumber documented moderate antimicrobial activity against Pseudomonas aeruginosa. (Farouk et al., 2007) and also the ethyl alcohol extracts of rose petals also showed antimicrobial activity against $P$ seudomonas aeruginosa ATCC 27853 was reported Farouk et al., 2014).

Wider studies pertaining to the use of plants (about $14 \mathrm{~mm}$ as therapeutic agents should be emphasized, especially those related to the control of antibiotic resistant microbes). The results obtained also showed that the ethyl alcohol extracts of flower and latex of Calotropis procera showed moderate antimicrobial activity against Bacillus subtilis ATCC6633 in same concentrations (diameter $10 \mathrm{~mm}$. and $8 \mathrm{~mm}$.). The ethanolic extracts of roots of Calotropis procera has potential activity against the tested pseudomonas aeruginosa was also already reported (Swapnali et al., 2012). In isoamyl alcohol and acetone extracts of fruit showed an activity in all four bacteria except Candida albicans ATCC 10231. The alcoholic and acetone extracts of the leaves and stem extracts of from Eurycoma longifolia (Tongkat Ali) and Labisia pumila (Kacip Fatimah) and their purified peptides were active against both Gram-positive and Gram-negative bacteria except against 2 strains of Gram-negative bacteria (Escherichia coli and Salmonella typhi) (Farouk, et al., 2007 \& 2008).

Though the distilled water and Zamzam water extracts of leaves, flower, fruit, latex and Tris- $\mathrm{HCl}$ at $\mathrm{pH} 8.9(100 \mathrm{mM})$ extracts of fruit and latex of Calotropis procera had shown an activity against Bacillus subtilis ATCC6633 in same concentrations (diameter $8 \mathrm{~mm}$ ), no activity was found for Tris- $\mathrm{HCl}$ at $\mathrm{pH} 8.9(100 \mathrm{mM})$ extracts of leaves and flowers of Calotropis procera against Bacillus subtilis ATCC6633. Water extracts of leaves, flower and fruit showed significant activity against both Gram positive and Gram negative strains as reported earlier (Yesmin et al., 2008, Mainasara et al., 2011). The bacteria 
isolated from flowers of Rosa damascena cv. Taifi also showed antimicrobial activity and enzymatic activities were reported by Farouk et al., (Farouk et al., 2014).

The acetonic extracts of leaves, flowers, fruits and latex extracts of Calotropis procera had varying inhibitory effects (6 to
$8 \mathrm{~mm}$ ) on most of the four tested microorganisms as represented in Table 1 except Candida albicans ATCC 10231 with nil antimicrobial activity. The acetonic extracts of various leaves showed considerable activity against tested microorganisms (Al-Kahtani et al., 2000).

Table.1 Antimicrobial activities (inhibition zones $\mathrm{mm} / \mathrm{ml}$ ) of leaves, flowers, fruits and latex of Calotropis procera extracted with 6 Different solvents VS 5 microorganisms.

\begin{tabular}{|c|c|c|c|c|c|c|c|}
\hline \multirow[t]{2}{*}{ Bacteria } & \multirow{2}{*}{$\begin{array}{c}\text { Calotropis } \\
\text { procera } \\
\text { (Parts) }\end{array}$} & \multicolumn{6}{|c|}{$\begin{array}{l}\text { Antimicrobial activities of Calotropis procera in } 200 \mathrm{mg} / \mathrm{ml} \\
\text { Inhibition zones ( } \mathrm{mm} \text { ) with different solvents. }\end{array}$} \\
\hline & & $\begin{array}{c}\text { Distilled } \\
\text { water } \\
(\mathrm{mm})\end{array}$ & $\begin{array}{l}\text { Zamza } \\
m \\
(\mathrm{~mm})\end{array}$ & $\begin{array}{c}\text { Ethyl } \\
\text { alcoho } \\
1 \\
(\mathrm{~mm})\end{array}$ & $\begin{array}{c}\text { Aceton } \\
\mathrm{e} \\
(\mathrm{mm})\end{array}$ & $\begin{array}{c}\text { Isoamyl } \\
\text { alcohol } \\
(\mathrm{mm})\end{array}$ & $\begin{array}{l}\text { Tris- } \\
\mathrm{HCl} \\
(\mathrm{mm})\end{array}$ \\
\hline Bacillus subtilis & & $6 \pm 2$ & $6 \pm 2$ & $6 \pm 2$ & $6 \pm 2$ & $6 \pm 2$ & -- \\
\hline Escherichia coli & & $4 \pm 2$ & $4 \pm 2$ & $4 \pm 2$ & $4 \pm 2$ & $4 \pm 2$ & $4 \pm 2$ \\
\hline Candida albicans & & -- & -- & $8 \pm 2$ & -- & -- & -- \\
\hline Micrococcus leutus & Leaves & $4 \pm 2$ & $4 \pm 2$ & $4 \pm 2$ & $4 \pm 2$ & $4 \pm 2$ & $6 \pm 2$ \\
\hline $\begin{array}{l}\text { Pseudomonas } \\
\text { aeroginosa }\end{array}$ & & $2 \pm 2$ & $4 \pm 2$ & $8 \pm 2$ & $4 \pm 2$ & $2 \pm 2$ & $2 \pm 2$ \\
\hline Bacillus subtilis & & $6 \pm 2$ & $6 \pm 2$ & $8 \pm 2$ & $6 \pm 2$ & $6 \pm 2$ & -- \\
\hline Escherichia coli & & $4 \pm 2$ & $4 \pm 2$ & $4 \pm 2$ & $4 \pm 2$ & $4 \pm 2$ & $4 \pm 2$ \\
\hline Candida albicans & & -- & -- & -- & -- & -- & -- \\
\hline Micrococcus leutus & Flowers & $4 \pm 2$ & $4 \pm 2$ & $4 \pm 2$ & $4 \pm 2$ & $4 \pm 2$ & $4 \pm 2$ \\
\hline $\begin{array}{l}\text { Pseudomon } \\
\text { asaeroginosa }\end{array}$ & & $4 \pm 2$ & $2 \pm 2$ & $4 \pm 2$ & $4 \pm 2$ & -- & -- \\
\hline Bacillus subtilis & & $6 \pm 2$ & $6 \pm 2$ & $6 \pm 2$ & $6 \pm 2$ & $6 \pm 2$ & $4 \pm 2$ \\
\hline Escherichia coli & & $4 \pm 2$ & $4 \pm 2$ & $4 \pm 2$ & $4 \pm 2$ & $4 \pm 2$ & -- \\
\hline Candida albicans & & -- & -- & -- & -- & -- & -- \\
\hline Micrococcus leutus & Fruit & $4 \pm 2$ & $4 \pm 2$ & $4 \pm 2$ & -- & $4 \pm 2$ & $4 \pm 2$ \\
\hline $\begin{array}{l}\text { Pseudomonas } \\
\text { aeroginosa }\end{array}$ & & $4 \pm 2$ & $4 \pm 2$ & $4 \pm 2$ & $4 \pm 2$ & $4 \pm 2$ & -- \\
\hline Bacillus subtilis & & $6 \pm 2$ & $6 \pm 2$ & $6 \pm 2$ & $6 \pm 2$ & $6 \pm 2$ & -- \\
\hline Escherichia coli & & $4 \pm 2$ & $4 \pm 2$ & $4 \pm 2$ & $4 \pm 2$ & $4 \pm 2$ & $4 \pm 2$ \\
\hline Candida albicans & latex & -- & -- & -- & -- & -- & -- \\
\hline Micrococcus leutus & & -- & -- & -- & $4 \pm 2$ & -- & -- \\
\hline $\begin{array}{l}\text { Pseudomonas } \\
\text { aeroginosa }\end{array}$ & & -- & $4 \pm 2$ & -- & $4 \pm 2$ & $4 \pm 2$ & $8 \pm 2$ \\
\hline
\end{tabular}


Table.2 Antimicrobial activities (inhibition zones $\mathrm{mm} / \mathrm{ml}$ ) of different microorganisms VS oxytetracycline

\begin{tabular}{cccccc}
\hline Standard $(\mu \mathrm{g} / \mathrm{ml})$ & $\begin{array}{c}\text { Bacillus } \\
\text { subtilis } \\
(\mathrm{mm})\end{array}$ & $\begin{array}{c}\text { Escherichia } \\
\text { coli } \\
(\mathrm{mm})\end{array}$ & $\begin{array}{c}\text { Candida } \\
\text { albicans } \\
(\mathrm{mm})\end{array}$ & $\begin{array}{c}\text { Micrococcus } \\
\text { Leutus } \\
(\mathrm{mm})\end{array}$ & $\begin{array}{c}\text { Pseudomonas } \\
\text { aeroginosa }(\mathrm{mm})\end{array}$ \\
\hline $\begin{array}{c}\text { oxytetracycline at } \\
1.0 \mu \mathrm{g} / \mathrm{ml}\end{array}$ & $3.5 \pm 0.2$ & $6 \pm 0.1$ & $6.5 \pm 0.2$ & $4 \pm 0.2$ & $2.9 \pm 0.1$ \\
\hline
\end{tabular}

Table.3 Inhibition zones indicated with the numbers (Fig 2 \& Fig 3) and their corresponding order of extracts of leaves, flowers, fruits and latex of Calotropis procera extracted with 6 Different solvents used

\begin{tabular}{|c|c|c|}
\hline \multirow{5}{*}{$\begin{array}{l}\text { Inhibition zones } \\
\text { indicated with } \\
\text { the numbers }\end{array}$} & $\begin{array}{l}\text { Petri dish BS1 containing Bacillus } \\
\text { Subtilis in Fig } 2 \text { OR }\end{array}$ & $\begin{array}{l}\text { Second Petri dish BS2 containing Bacillus Subtilis in } \\
\text { Fig2 OR }\end{array}$ \\
\hline & $\begin{array}{l}\text { Petri dish PA1 containing } \\
\text { P.aeroginosa in Fig } 2 \text { OR }\end{array}$ & $\begin{array}{l}\text { Second Petri dish PA2 containing P.aeroginosa in Fig2 } \\
\text { OR }\end{array}$ \\
\hline & $\begin{array}{l}\text { Petri dish EC1 containing } \\
\text { Escherichia coli in Fig } 3 \text { OR }\end{array}$ & $\begin{array}{l}\text { Second Petri dish EC } 2 \text { containing Escherichia coli in } \\
\text { Fig } 3 \text { OR }\end{array}$ \\
\hline & $\begin{array}{l}\text { Petri dish ML1 containing } \\
\text { Micrococcus leutus in Fig } 3 \text { OR }\end{array}$ & $\begin{array}{l}\text { Second Petri dish ML2 containing Micrococcus leutus } \\
\text { in Fig } 3 \text { OR }\end{array}$ \\
\hline & $\begin{array}{l}\text { Petri dish CA1 containing Candida } \\
\text { albicans in Fig } 3 \\
\text { OR }\end{array}$ & $\begin{array}{l}\text { Second Petri dish CA2 containing Candida albicans in } \\
\text { Fig } 3\end{array}$ \\
\hline 2 to 7 & $\begin{array}{c}\mathrm{L} \\
\text { (Order LD, LZ, LE, LA , LI, LT) }\end{array}$ & Nil \\
\hline 8 to 13 & $\begin{array}{c}\text { F } \\
\text { (Order FD, FZ, FE, FA, FI, FT); }\end{array}$ & Nil \\
\hline 14 to 16 & $\begin{array}{c}\text { B } \\
\text { (Order BD, BZ, BE); }\end{array}$ & Nil \\
\hline 17 & Ethyl alcohol & Nil \\
\hline 18 & Acetone & Nil \\
\hline 20 to 22 & Nil & $\begin{array}{c}\mathrm{B} \\
\text { (order: } \mathrm{BA}, \mathrm{BI}, \mathrm{BT})\end{array}$ \\
\hline 23 to 28 & Nil & $\begin{array}{c}\text { M } \\
\text { (order MD MZ,ME,MA,MI,MT }\end{array}$ \\
\hline 29 & Nil & Ethyl alcohol \\
\hline 30 & Nil & Acetone \\
\hline
\end{tabular}


Fig.1 Flowchart of the methodology

Leaves, Flowers, Fruits of Calotropis procera were washed with sterilized distilled water followed by disinfectant ethyl alcohol and were collected from the rose flower buds.

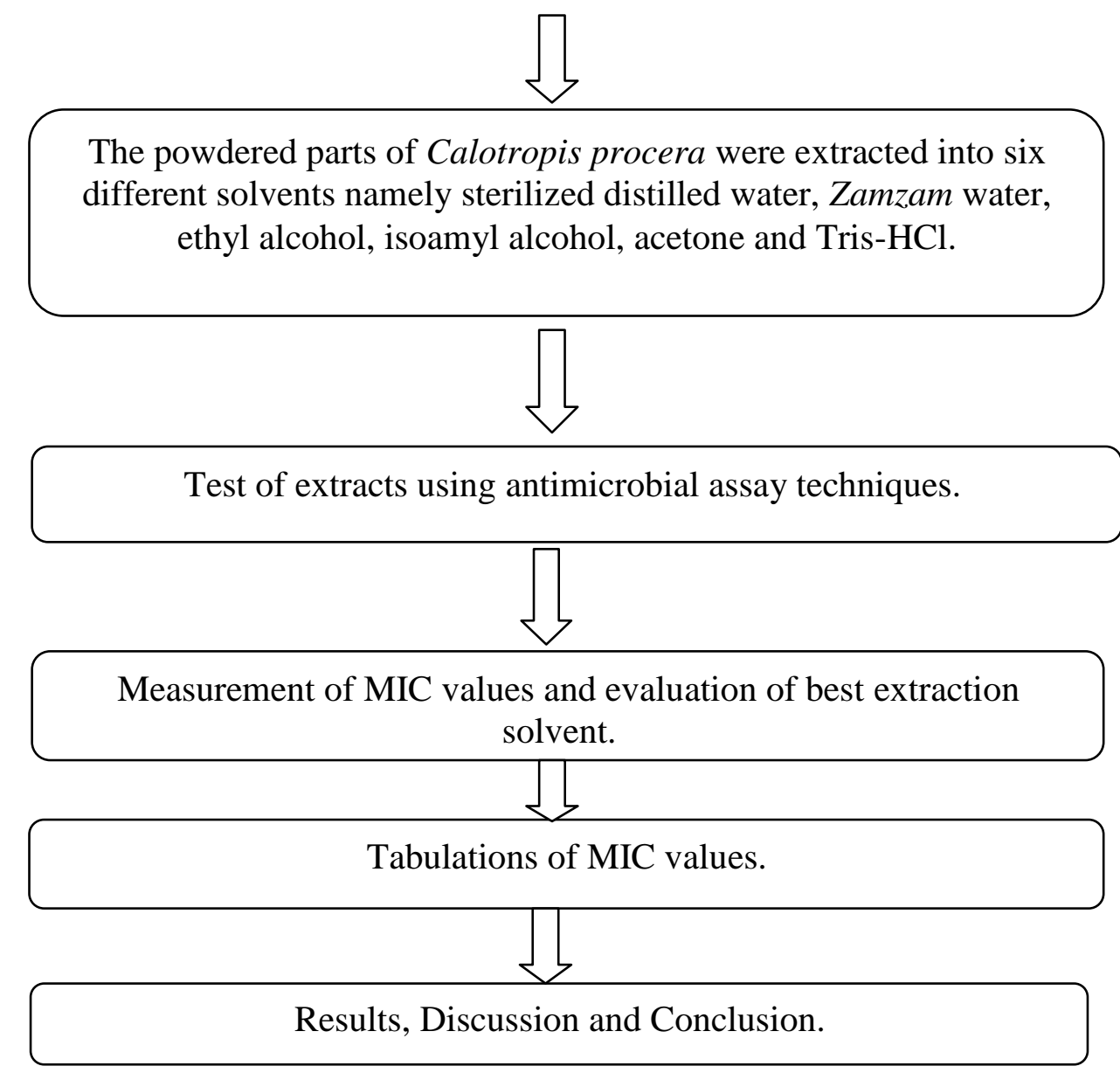


Fig.2 The antimicrobial activity of leaves, flowers, fruits, latex of Calotropis procerain different aqueous solutions and solvents such as sterilized Zamzam water, distilled water, ethanol, acetone, isoamyl alcohol and $100 \mathrm{mM}$ Tris- $\mathrm{HCl}$ at $\mathrm{pH} 8.7$ using liquid Nitrogen with

Bacillus subtilis and Pseudomonas aeroginosa.

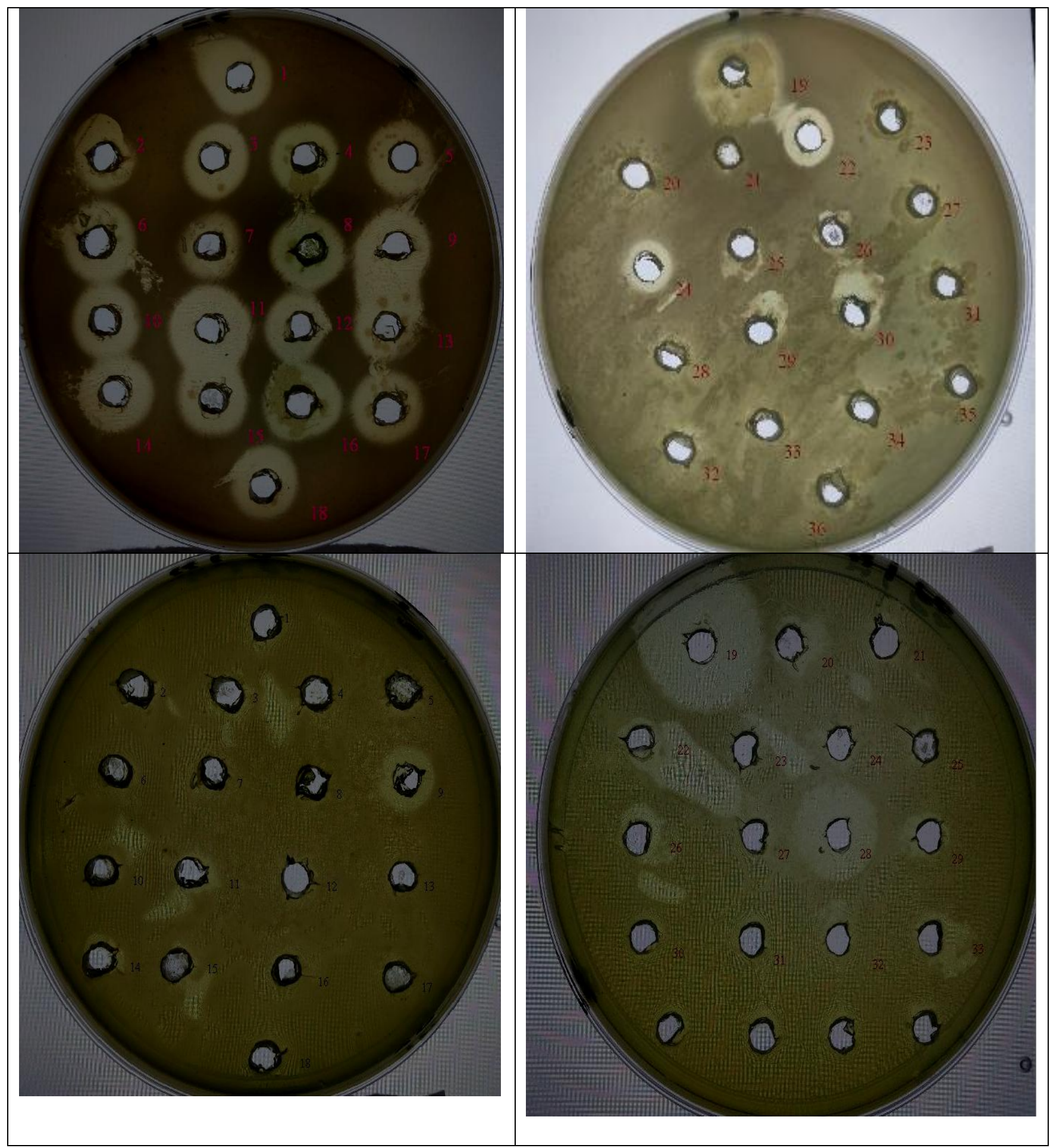


Fig.3 The antimicrobial activity of leaves, flowers, fruits, latex of Calotropis procera in different aqueous solutions and solvents such as sterilized Zamzam water, distilled water, ethanol, acetone, isoamyl alcohol and $100 \mathrm{mM}$ Tris- $\mathrm{HCl}$ at $\mathrm{pH} 8.7 \mathrm{using}$ liquid Nitrogen with Escherichia coli and Micrococcus leutus

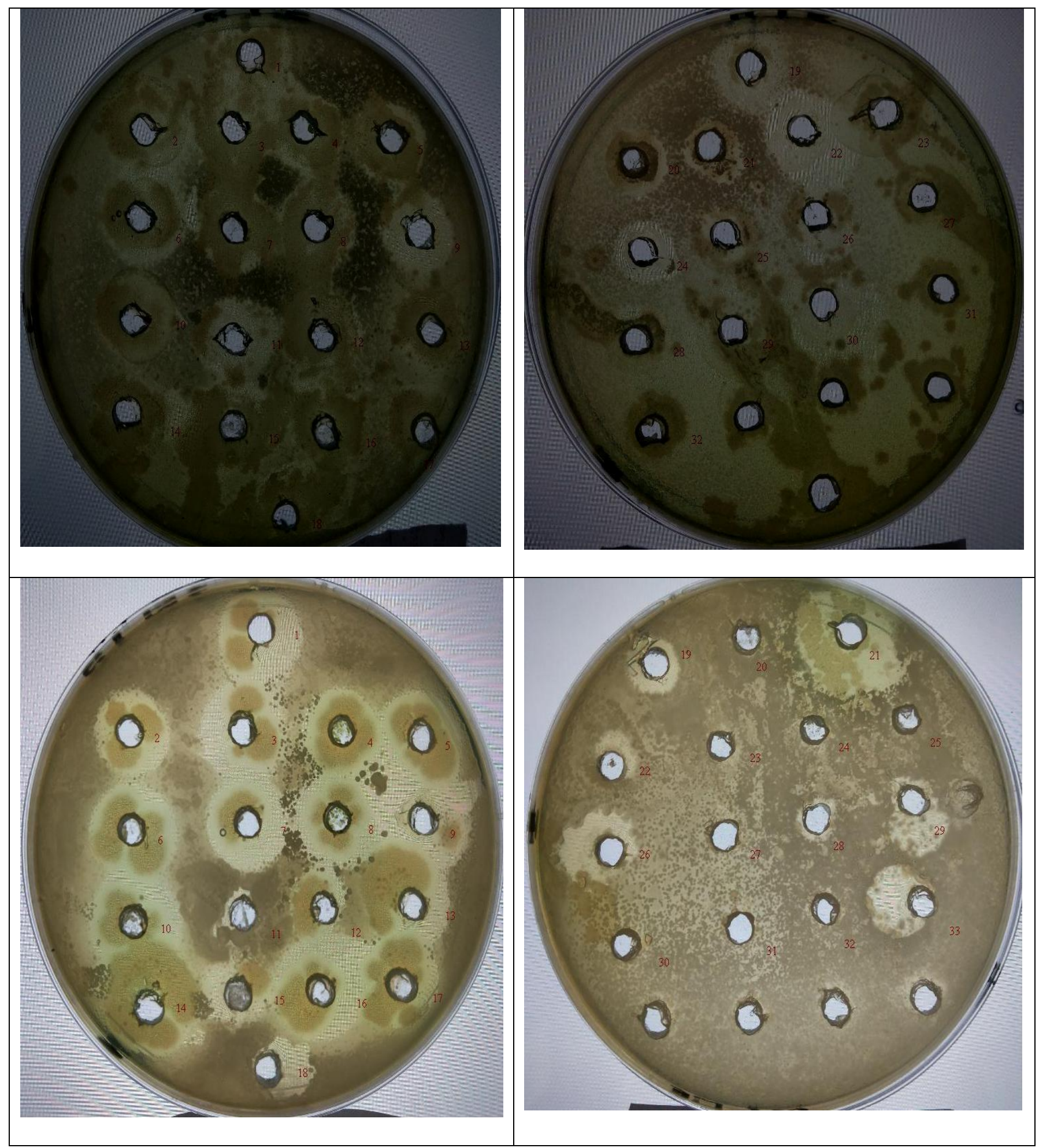


Fig.4 The antimicrobial activity of leaves, flowers, fruits, latex of Calotropis procera in different aqueous solutions and solvents such as sterilized Zamzam water, distilled water, ethanol, acetone, isoamyl alcohol and $100 \mathrm{mM}$ Tris- $\mathrm{HCl}$ at pH 8.7 using liquid Nitrogen with

\section{Candida albicans}

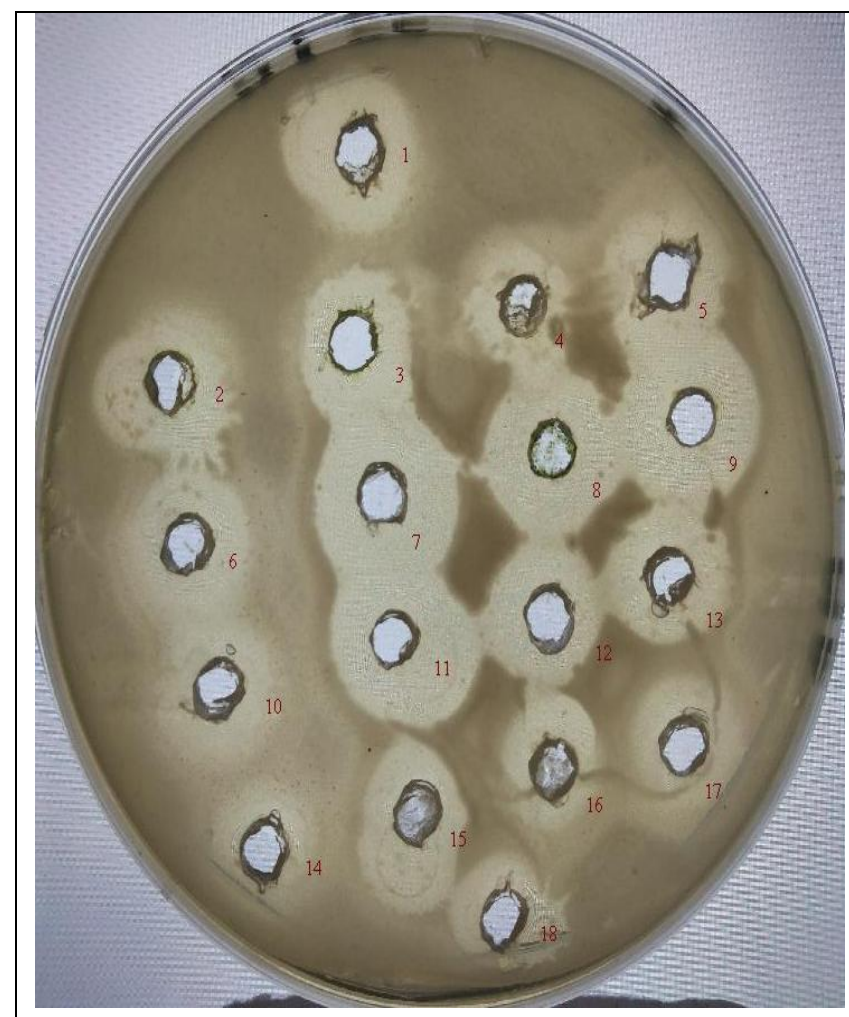

Inhibitions zones from 4 to $6 \mathrm{~mm}$ for Zamzam and sterilized distilled water extracts of fruit of Calotropis procera were observed for the Escherichia coli ATCC 8739, Micrococcus luteus ATCC 9341 and Pseudomonas aeruginosa ATCC 27853. Water and ethanolic extracts of fruit showed antimicrobial activity against pseudomonas was also reported (Mainasara et al., 2011)). In isoamyl alcohol and acetone extracts of fruit of Calotropis procera, antimicrobial activity found in all four bacteria except Candida albicans ATCC 10231.

The Tris- $\mathrm{HCl}$ at $\mathrm{pH} 8.9(100 \mathrm{mM})$ extracts of latex extracts of Calotropis procera showed considerable $(14 \mathrm{~mm})$ antimicrobial activity against Bacillus subtilis ATCC 6633, moderate $(8 \mathrm{~mm})$ antimicrobial

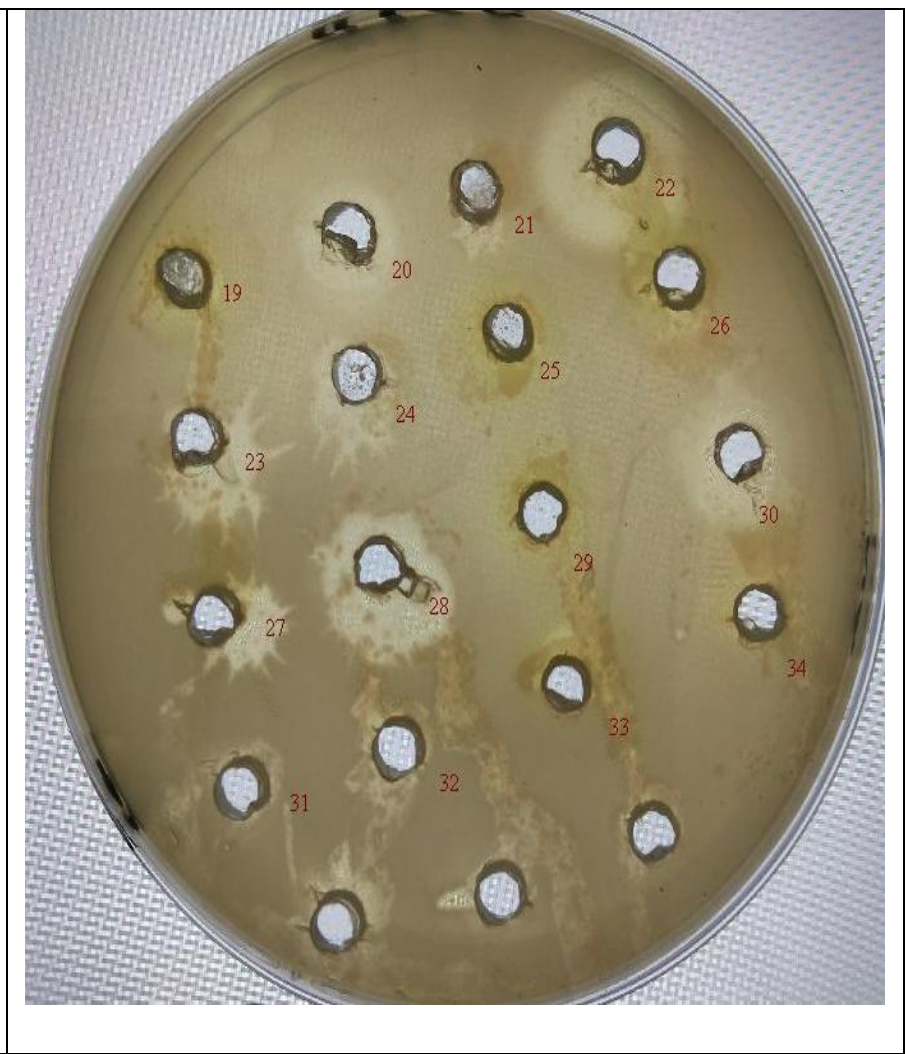

activity against Micrococcus luteus ATCC 9341 and good $(6 \mathrm{~mm})$ antimicrobial activity against Escherichia coli and Pseudomonas aeruginosa. Also the Tris- $\mathrm{HCl}$ pH 8.9 (100 $\mathrm{mM}$ ) extracts of leaves of Calotropis procera had shown best result $(10 \mathrm{~mm})$ which is similar to the ethyl alcohol extract of leaves extracts of Calotropis procera against Pseudomonas aeruginosa ATCC 27853.

$200 \mathrm{mg} / \mathrm{ml}$ fruit extracts of Calotropis procerain all solvents showed activity against tested organisms except nil activity in Candida albicans ATCC 10231. The Tris- $\mathrm{HCl}$ at $\mathrm{pH} 8.9(100 \mathrm{mM})$ extracts of fruit extracts of Calotropis procera showed activity for Bacillus subtilis ATCC 6633 and Micrococcus luteus ATCC 9341. 
In this study, the ethyl alcohol and acetone extracts of leaves extracts of Calotropis procera showed excellent results against Pseudomonas aeruginosa and Candida albicans ATCC 10231. The ethyl alcohol extracts of flower and latex showed moderate antimicrobial activity against Bacillus subtilis ATCC6633 in same concentrations (diameter $10 \mathrm{~mm}$. and 8 $\mathrm{mm}$.).

The distilled water and Zamzam water extracts of leaves, flower, fruit, latex and Tris- $\mathrm{HCl}$ at $\mathrm{pH} 8.9(100 \mathrm{mM})$ had shown activity against Bacillus subtilis ATCC6633 in same concentrations (diameter from 8 to $12 \mathrm{~mm}$ ). In isoamyl alcohol and acetone, extracts of fruit showed activity in all four bacteria except Candida albicans ATCC 10231. The resourceful Calotropis procera which contains rich antimicrobial sources needs to be further studied in order to confirm the purification of the antimicrobial compounds. The Calotropis procera should be investigated to better understand their antimicrobial properties, safety and efficiency. The present study revealed that there is a possibility for developing novel eco-friendly antimicrobial or antiviral drugs from Calotropis procera against aquatic vital pathogens. In this study, different solvent extracts proved that Calotropis procera has medicinal values.

\section{Acknowledgment}

The authors express their gratitude to Taif University, for their Grant 928/431/1, AlHawiya 888, Kingdom of Saudi Arabia, Deputy President for postgraduates and Research Prof. Saad Alzahrani and the support of the Dean of Science. Also, the authors extend their sincere gratitude for the support of the Biotechnology Department of Taif University, Saudi Arabia for its financial support for these research efforts.

\section{References}

Agharkar, S.P. 1991. Medicinal Plants of Bombay Presidency. Scientific Publ., India. p. 48-49.

Ali, N.O., El-Rabaa, F.M. 2010. Larvicidal activity of some plant extracts to larvae of the mosquito Culex quinquefasciatus (Say 1823). Eur. Rev. Med. Pharmacol Sci. 14(11): 925-933.

Alikhan, I., Khanum, A. 2005. Medicinal and Aromatic Plants of India. Ukaaz Publication; pp. 133-4.

Al-Kahtani, J.S.M., Al-Yahya, M.A., AlMeshal, I.A. 2000. Medicinal plants of Saudi Arabia (Volume II). Department of Pharmacognosy, College of Pharmacy, King Saud University, Riyadh, Saudi Arabia.

Ansari, S.H., Ali M 1999. New oleanene triterpenes from root bark of Calotropis procera. Medic. \& Aromatic Plant Sci. 21(4): 978-981.

Collins, C.H., Lynes P.M., Grange J.M. 1995. Microbiological Methods (7th edition). Butterwont-Heinemann, Ltd, Britain pp. 175-190.

DeFreitas, C.D.T., Sousa Nogueira, F.C., Vasconcelos, I.M., Oliveira, J.T.A., Domont, G.B., Ramos, M.V. 2011.Osmotin purified from the latex of Calotropis procera: Biochemical characterization, biological activity and role in plant defense. Plant Physiol. Biochem. 49:738-743.

DEnfert, C., Hube, B (editors) 2007. Candida: Comparative and Functional Genomics. Caister Academic Press.

Dewan, S., Kumar S., Kumar V.L .2000. Antipyretic effect of Latex of Calotropis procera. Indian Journal of Pharmacology 32:252.

Farouk, A., Asma, B. 2007. Antibacterial activity of Eurycoma longifolia, Jack; 
a Malaysian medicinal plant. Saudi Med. J., 28(9): 477.

Farouk, A., Banaja A., Thoufeekahamed N., Othman Ai, Salih B. 2014. Evaluation of antimicrobial activities of Rosa damascena cv. Taifi extract. African J. Biotechnol., 8(50): 39133917.

Farouk, A., Nawai M.N., Hassan S. 2008. Antibacterial Peptides from Eurycoma longifolia (Tongkat Ali) and Labisia pumila (Kacip Fatimah) Leaves in Malaysia. Sci Brun. 9: 5563.

Francis, J.K.2002. Calotropis procera (Ait.) Ait. In: Francis JK, ed. Wild land shrubs of theUnited States and its territories: thamnic descriptions. USDA Forest Service General Technical Report IITF-WB-1. Vol 1, pp 830.

Hiren, D., Hitesh S, Mukund C.T., Farzin P., Arif K. 2011. Phytochemical Screening and Biological Activity of Calotropis procera (Ait). R. Br. Asclepiadaceae) against selected bacteria and Anopheles stephansi Larvae. Int. J. Plant Res., 1(1): 29-33

Ishnava, K.B., Chauhan J.B., Garg A.A, Thakkar A.M. 2012. Antibacterial and phytochemical studies on Calotropis gigantia (L.) R.Br. Latex against selected carcinogenic bacteria. Saudi J. Biol. Sci.19 (1): 87-91.

Jain, P.K., Verma R., Kumar N., Kumar A. 1985. Clinical trial of Arka-MulatwakBark ofCalotropis procera - a preliminary study. J Res. Ayur Sidha 6: 88-91.

Joshua, L., Martin, A., Barry, R.B. 2000. Encyclopedia of Microbiology.Vol.1. Joshua Academic Press.

Little, E.L., Jr, Woodbury, R.O., Wadsworth, F.H. 1974. Trees of Puerto Rico and the Virgin Islands,
Vol. 2. Ag. Handbook 449. Washington, DC, USA: USDA.

Kareem, S.O., Akpan I., Ojo O.P. 2008. Antimicrobial Activities of Calotropis procera on Selected Pathogenic Microorganisms. African Journal of Biomedical Research. 11:105 - 110.

Kumar, V.L., Chaudhary P., Ramos M.V., Mohan M., Matos M.P. 2011. Protective effect of proteins derived from the latex of Calotropis procera against inflammatory hyperalgesia in monoarthritic rats. Phytother Res. 25(9): 1336-41.

Larhsini, M., Oumoulid L., et al., 1999. Screening of antibacterial and antiparasitic activities of six Moroccan medicinal plants. Therapie London, 54(6):763-765.

Lederberg, J. 2000. Encyclopedia of Microbiology, 2nd ed. Academic Press, San Diego pp 677-97.

Lima-Filho, J.V., Patriota, J.M., Silva, A.F., Filho, N.T., Oliveira, R.S., Alencar, N.M., Ramos, M.V. 2010. Proteins from latex of Calotropis procera prevent septic shock due to lethal infection by Salmonella enterica serovar Typhimurium. J. Ethnopharmacol., 129(3): 327-334.

Madigan, M., Martinko, J. (editors) 2005. Brock Biology of Microorganisms (11th edition.). Prentice Hall, U.S.A. pp. 545-572.

Magalhaes, H.I., Ferreira, P.M., Moura, E.S., Torres, M.R., Alves, A.P., Pessoa, O.D., Costa- Lotufo, L.V., Moraes, M.O., Pessoa, C. 2010. In vitro and in vivo antiproliferative activity of Calotropis procera stem extracts. An Acad. Bras Cienc. 82(2): 407-416.

Mainasara, M.M,. Aliero, B.L., Aliero, A.A, Dahiru, S.S. 2011. Phytochemical and antibacterial properties of Calotropis procera (Ait.) R. Br Fruit and bark 
extracts. Int. J. Modern Botany, 1(1): 8-11.

Markouk, M., Bekkouche, K., Larshini, M., Bousaid, M., Lazrek, HM, Jana, M. 2000. Evaluation of some Moroccan medical plant extracts for larvicidal activity. J. Ethnopharmacol., 73(1-2): 293-297.

Mascolo et al., 1988. Moroccan medical plant extracts for larvicidal activity. $J$. Ethnopharmacol. 73(1-2): 293-297.

Morsy, T.A., Rahem, M.A., Allam, K.A. 2001. Control of Musca domestica third instar larvae by the latex of Calotropis procera (Family: Asclepiadaceae). J. Egypt Soc. Parasitol. 31(1): 107-110.

Mst Nazma, Y., Sarder N.U., Sanzida Mand Muhammad A.A. 2008. Antioxidant and Antibacterial Activities of Calotropis procera Linn. AmericanEurasian J. Agr. \& Environ. Sci. 4(5): 550-553.

Muraina, I.A., Adaudi, A.O., Mamman, M., Kazeem, H.M., Picard, J., McGaw, L.J., $\quad$ Eloff, J.N. 2010. Antimycoplasmal activity of some plant species from northern Nigeria compared to the currently used therapeutic agent. Pharm. Biol. 48(10): 1103-1107.

Murti, Y., Yogi B., Pathak, D. 2010. Pharmacognostic standardization of leaves of Calotropis procera (Ait.) R. Br. (Asclepiadaceae). Int. J. Ayurveda Res. 1: 14-17.

Njama, D. 2009. Trees and shrubs of East Africa. p 207.

Nour, Z., Rita, K. 2010. A comparative study between the chemical composition of potable water and Zamzam water in Saudi Arabia in zamzam water publication article. p. 19.

Oliveira, J.S., Costa-Lotufo, L.V., Bezerra, D.P., Alencar, N.M., Marinho-Filho,
J.D.,

Figueiredo, I.S., Ramos, M.V. 2010. In vivo growth inhibition of sarcoma 180 by latex proteins from Calotropis procera. Naunyn Schmiedebergs Arch. Pharmacol. 382: 139-149.

Raghubir, R., Rasik M., Gupta A.J. 1999. Healing potential of Calotropis procera on dermal wounds in guinea pigs. J. Ethnopharmacol. 68:261-6.

Rama, P., Vasantha, 2012. Phytochemical and antibacterial activity of Calotropis procera (Ait.) R.Br Flowers. Int. J. Pharma and Bio Sci., 3(1):1-5.

Ramar, P.S., Vincent, T. K. Chow, 2012. Pilot Study with regard to the Wound Healing Activity of Protein from Calotropis procera (Ait.) R. Br. Evidence-Based Complementary and Alternative Medicine. Volume 2012: 1-11.

Russo, E., 2003. "The birth of biotechnology". Nature, 421 (6921): 456-457.

Ryan, K.J., Ray, C.G. (editors) 2004. Sherris Medical Microbiology: an introduction to infectious diseases. (4th edition). Newyork: McGraw Hill. ASM Press, Washington.

Sambrook, J., Russell, D.W. 2001. Molecular Cloning, a Laboratory Manual, 3rd edition. Cold Spring Harbor, NY: Cold Spring Harbor Laboratory Press.

Samvatsar, S., Diwanji V.B. 2000. Plant sources for the treatment of jaundice in the tribals of Western Madhya Pradesh of India. J. Ethnopharmacol. 73:313-316.

Shahi, M., Hanafi-Bojd A.A., Iranshahi, M., Vatandoost H., Hanafi-Bojd M.Y. 2010. Larvicidal efficacy of latex and extract of Calotropis procera (Gentianales: Asclepiadaceae) against Culex quinquefasciatus and Anopheles stephensi (Diptera: Culicidae). J. 
Vector Borne Dis. 47: 185-188.

Sharma, A.K., Kharib, R., Kaur, 2011. Pharmacognostical aspects of Calotropis procera. Int. J.of pharma and biosciences. 2(3): 480-488.

Shivpuri, A., Sharma, O.P., Jhamaria, S.L. 1997. Fungi toxic properties of plant extracts against pathogenic fungi. $J$. Mycol. plant Pathol., 27:29-31.

Shoaib, Q, Kumkum, M, Sandeep, A 2013. Calotropis procera: An overview of its phytochemistry and pharmacology. Indian J. Drugs 1(2): 63-69.

Shomar, B. 2012. Concentration of trace elements and other characteristics. Chemosphere. 86(6):600-605.

Silva, M.C.C., aSilva, A.B., Teixeira, F.M., DeSousa, P.C.P., Rondon, R.M.M., Junior JERH, 2010. Therapeutic and biological activities of Calotropis procera (Ait.) R.Br. Asian Pac. J. Trop. Med., 3:332-336.

Singh, U.A.M, Wadhwani, B.M, Johri, 1996. Dictionary of Economic Plants of India. Indian Council of Agricultural Research, New Delhi.45146.

Soneera, A., Vijay, L.K. 2005. Antiinflammatory Efficacy of Extracts of Latex of Calotropis procera Against Different Mediators of Inflammation. Mediators of Inflammation. 4: 228232.
Souza, D.P., Freitas, C.D., Pereira, D.A., Nogueira, F.C., Silva, F.D., Salas, C.E., Ramos, 2011. Laticifer proteins play a defensive role against hemibiotrophic and necrotrophic phytopathogens. Planta. 234(1): 183193.

Subramanian, V., Vijayaragavan, T.V., Mariavincent, M.B., Mary, J.P., Thavasimuthu C. 2012.Antimicrobial effect of Calotropis procera active principles against aquatic microbial pathogens isolated from shrimp and fishes. Asian Pacific J. Tropical Biomed., 2(2): S812-S817.

Swapnali, M.G., Madhuri, V.P., $\begin{array}{ll}\text { Raghunathah, } & \text { T.M. } 2012 .\end{array}$ Phytochemical screening and antibacterial activity of ethanol extracts of Calotropis procera root. Int. J. Res. Phytochemistry \& Pharmacol., 2(3): 143-146.

Verma, R., Satsangi, G.P., Shrivastava, J.N. 2010. Ethno-medicinal profile of different plant parts of Calotropis procera (Ait.) R. Br. Ethno botanical Leaflets, 14: 721-742.

Yesmin, M.N., Uddin, N.S., Sanzida, M., Muhammad, A.A. 2008. Antioxidant and Antibacterial Activities of Calotropis procera. AmericanEurasian J. Agric. and Environ. Sci., 4(5): 550-553.

\section{How to cite this article:}

Abd-El Aziem Farouk, N. Thoufeek Ahamed, Othman AlZahrani, Khalid H. Alamer and Abdul Aziz Bahobail. 2016. Antimicrobial Activities Evaluation from the Extracts of Leaves, Flowers, Fruits and Latex of Calotropis procera from Taif. Int.J.Curr.Microbiol.App.Sci. 5(11): 240-256. doi: http://dx.doi.org/10.20546/ijcmas.2016.511.026 